\title{
Empty time (Peru under the pandemic)
}

\section{Mijail Mitrovic ${ }^{1}$ (D)}

Published online: 1 September 2020

(C) Springer Nature B.V. 2020

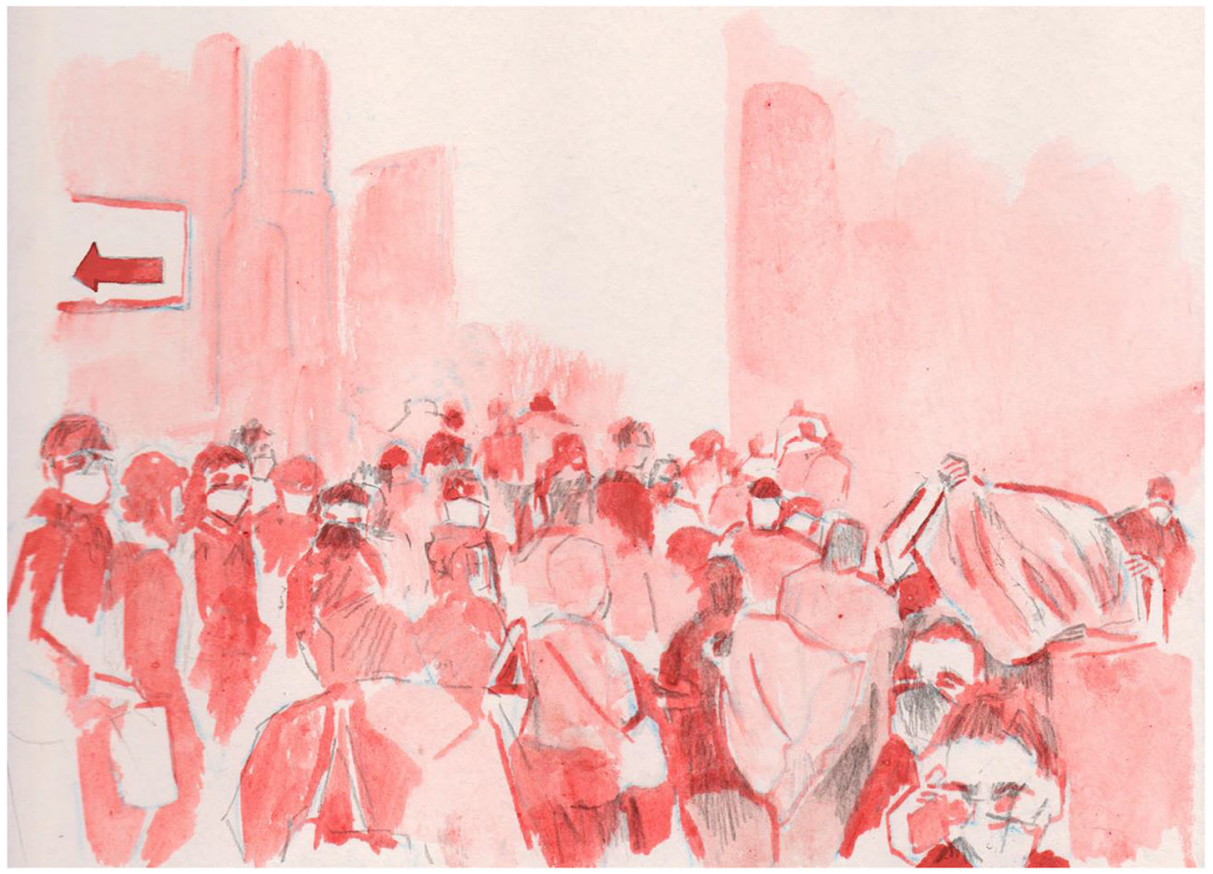

Illustration by Fernando Nureña.

In the midst of the lockdown, a mother and her daughter move from the so-called periphery of Lima to better-off neighbourhoods to ring bells from building to building. They ask for something, whatever someone in a better position can give them. The streets show the helplessness of those who do not even have the prospect of working for someone, that is, of being exploited by someone under whatever conditions. Charity becomes the only hope in the absence of work. Another day, a poor man waits for someone to come out of his house to kneel

$\triangle$ Mijail Mitrovic

m.mitrovic@pucp.edu.pe

$1 \quad$ Pontificia Universidad Católica del Perú, Lima, Peru 
down and ask him for work. Someone appears and quickly, already from below, he could recite: "Lord/I am so poor/that the only/offering/that I could bring/is me".

Dalmacia Ruiz Rosas' poem (from her book Secuestro en el jardín de las rosas, 1998) recalls previous crises in the country, where the notion of proletarianization - the process of dispossession of livelihoods and means of production, with its correlative reduction of the subject to a body, a mere support of labour power - acquired a very concrete meaning. Of course, in addition to the number of deaths radically higher than official records, these little more than 100 days of quarantine in Peru mean a significant drop in the GDP and a dark outlook for the country if we follow the development path imposed 30 years ago. But, above all, they account for an accelerated transition towards a mass proletarianization - not only precarization of current working conditions but also radical dispossession.

It is not just raw data of job losses, which can already be seen in the last 2 months. In a country where 7 out of 10 occupations of the economically active population is based on informal labour, it is key to look beyond the data to understand the qualitative change in the life situation to which this crisis pushes us, and in particular how the working class will be compelled to go to the market to seek or beg for some solution to their misery.

This situation had already come to light in recent years with the Venezuelan migration crisis, which returned the urban landscape to the image of the street as a place of indigence, ambulatory commerce and child labour prior to the so-called Peruvian miracle that boosted the economy for a decade without weaving a public network of social protection. The pandemic will end up saturating the urban space as a place of mendicancy and hopelessness. If in the last decades the idea that economic growth of the 2000s had led our social structure to transform from a pyramid to a rhombus was imposed on us, based on an alleged thickening of the middle class - measured by income and exalting its consumption capacity-, today without a doubt we assist in real time to the return of the Peruvian society to its historical pyramidal form. This is a real social collapse, beyond the accurate or tricky geometry of our social structure.

The government's response was swift, declaring a strict quarantine early on and allocating a significant sum of money to mitigate the crisis, but it proved insufficient. There is already a certain consensus on the difficulties inherent in our social structure in the face of the pandemic. The high degree of informal employment pushes millions of people onto the streets every day, as has been mentioned in multiple media. In addition, a large part of the population is not in a position to comply with strict quarantine: for example, only half of the households have a refrigerator, which led to markets being serious sources of contagion, and the small proportion of citizens with a bank account meant that there were serious limitations to the transfer of financial aid bonds.

However, the situation is not entirely explained by medium-term structural conditions. On the political level, several measures with popular support have gone through a process of modification that allows President Vizcarra to play in the media with a certain image of a ruler for the people that, however, listens closely to the demands of big business. A "universal aid bond" that does not reach everyone; a temporary tax on wealth, pious with large fortunes; a threat of expropriation of private clinics that is resolved with an agreement that is profitable for them, etc. As a counterpart, the business sector has benefited from the so-called "perfect suspension of work" that allowed it to get rid of thousands of workers very early in the pandemic, in addition to big business receiving large amounts of public money from the Reactiva Peru programme. ${ }^{1}$ The government has

\footnotetext{
${ }^{1}$ Of course, these tendencies of state rescue to big capitals are not exclusive to Peru. In this regard, see the recent interview with Vijay Prashad in: https://www.newsclick.in/Covid-19-Pandemic-Biggest-Failure-CapitalismHistory
} 
undoubtedly made some efforts to alleviate the impact of the crisis on the people, sometimes putting media impact before substantive action, but at the same time it has chosen to please business power, since it represents it directly.

At this juncture, the big Peruvian capitalists reveal their short-termism, demanding economic reactivation already underway, despite us being at a critical point of contagion. They seek for the rate of profit not to decrease, despite the fact that the source of value-human life, labour power - is threatened by the virus. The reactivation was also a demand raised from small entrepreneurs, those that our liberals like to see as the promises of a "popular capitalism" which, according to the preaching they insist on since the 1980s (in Hernando De Soto, for example), will one day lead the country to prosperity. Thus, the elite and the people would demand laissez faire in unison, and even the political scientist Alberto Vergara has suggested that "perhaps the majority [of Peruvians] are comfortable with the equilibrium of handle it as you see fit". A Peru "without law or fraternity" that perhaps "is desired from top to bottom: by the street vendor who appropriates the public highway and by the businessman who lobbies a tax exemption". ${ }^{2}$ The image is suggestive, but it is misleading since it supposes that those desires are formulated from comparable class positions, ${ }^{3}$ and leaves aside the fact that this "top-down" identification is the result of an active process of hegemonic construction which, still bumpy and counter-geared, reveals a fundamental agreement between the different fractions of the bourgeoisie. As shown by the survey of the Instituto de Estudios Peruanos last May, a large majority of the population considers that the magnitude reached by COVID19 in the country is the result of the individual irresponsibility of the citizens, but not of the government. ${ }^{4}$ This simple fact illustrates a common-sense consensus around the ways of conceptualizing social life typical of neoliberalism, and in this lies its hegemony.

However, there are fractures in the ruling class, and a portion of industrial capital does well to declare an alternative position to their union demand to return to normal, although they are a minority in our productive scheme. However, for CONFIEP (National Confederation of Private Business Institutions), it is not enough to have the government on their side. Their ideological work has not stopped: by various means, they have been declaring that this situation requires national unity, in the face of what, in their eyes, is a threat from the left to break its hegemony: "Let us not forget that when we speak of neoliberalism, we should also speak of neo-communism, because the truth is that the Berlin Wall fell in 1989 and class struggle and the dictatorship of the proletariat no longer exists, and therefore this is about generating well-being for the population, of generating opportunities", said Roque Benavides, former CONFIEP president. ${ }^{5}$ These are the ghosts of the ruling class, and their fear is justified by the opportunity that the crisis presents to change the course of the country.

In the context of last year's protests against neoliberal continuity in several Latin American countries, Peru was conspicuous by its absence, robbing Chile the title of regional "oasis" that Sebastián Piñera declared shortly before the outbreak of the riots. The management of the current crisis seems to contribute to make this figure of the neoliberal oasis our own, although

\footnotetext{
${ }^{2}$ See: Alberto Vergara, "La crisis del COVID-19 como Aleph Peruano", https://ciup.up.edu.pe/analisis/la-crisiscovid-19-como-aleph-peruano/

${ }^{3}$ See Jorge Frisancho's response to Vergara's essay in: http://www.noticiasser.pe/opinion/el-falso-aleph-dealberto-vergara

${ }^{4}$ Instituto de Estudios Peruanos, "Informe de opinión”, Mayo 2020, https://iep.org.pe/noticias/encuesta-deopinion-mayo-2020/

${ }^{5}$ See: https://www.rcrperu.com/roque-benavides-empleo-se-logra-con-proyectos-de-inversion-en-marcha-nocon-medidas-para-la-tribuna/
} 
we are very close to the world's peak in terms of the number of contagions. In this scenario, the government declares that we should not criticize its performance since structural problems are inherited from the bad management of the past. That heritage was inaugurated by the Fujimori's self-coup in 1992 that reconfigured the country and established the neoliberal guidelines in a new Constitution the following year, still in force and increasingly questioned, but Vizcarra's government insists on manoeuvring under its coordinates and proposing a horizon of reforms that will keep them intact.

Now, I would like to raise some ideas about what this crisis may mean for our historical experience. Above all, where do we return in historical terms and where can we go from here? The crisis of Alan García's first government (1985-1990) is still fresh in memory, a crisis where the economic collapse converged with the urban crisis and the Shining Path war ongoing since 1980. The current crisis activates the memory of those difficult years, and for many, the present is folding over historical time, taking us back to a situation similar to the 1980s, perhaps economically worse.

We are dealing with a critical form of destitution of what Walter Benjamin called empty and homogeneous time, a notion of time typical of a bourgeois idea of history too confident of progress, unable to perceive its intimate links with the past. ${ }^{6}$ This is a critical form because, of course, Benjamin thought that the intervention of the historian (his subjective figure of the revolutionary) in the present sought to redeem the past, the desires for emancipation defeated by those forces that never cease to overcome. However, today we see that empty time can also be filled by the memory of past disasters, which does not necessarily lead us to reactivate the energies of historical materialism in which Benjamin placed his trust despite the triumph of fascism.

Tithi Bhattacharya and Gareth Dale recently commented on the issue of bourgeois time in the face of the global crisis. I quote them extensively: "There is a dark temporal suicide embedded in these gestures of bourgeois denial. They ignore the warnings because their noses are at the windowpane of the present alone. The greatest achievement of the bourgeois discourse of Progress was the secularization of Time. Capitalist progress was projected through time as immanent, as coextensive with 'Nature'. Colonizing Europe harnessed this bourgeois Time to conquer Space: colonies, marked by their distance from the metropole, were cast as 'backward'. Our current crisis, cuing up ravaged futures and unmet potentials, is finally extinguishing this Immanent Time as it unmoors historical time from its long-held bourgeois tethers. Pathogens, forest fires and floods are de-naturalizing bourgeois empty time, stamping out its smooth progressive trajectory and reinvesting it with messianic lurches, breaks, and therefore possibilities". ${ }^{7}$ The Benjaminian tone of these words is remarkable, and it gives a dimension to the crisis from a perspective that, far from pessimism, brings us back to the need to go through it and take it as a historical opportunity. Although I think that messianic time still appears as a pure possibility.

We are living an instant that carries with it "its revolutionary opportunity", as Benjamin put it, but we must recognize "that it has to be defined in its specific singularity, that is, as the opportunity for a completely new solution to a completely new task". Faced with the rupture of the empty time that characterized the Peruvian experience of the last 30 years, socialism has no

\footnotetext{
${ }^{6}$ Translated into English on the basis of: Walter Benjamin, Tesis sobre la historia y otros fragmentos. Edición, traducción e introducción por Bolívar Echeverría. Ciudad de México: Universidad Autónoma de la Ciudad de México, Editorial Itaca, 2008.

${ }^{7}$ Tithi Bhattacharya and Gareth Dale, "Covid Capitalism: General Tendencies, Possible 'Leaps", Spectre Journal, April 23, 2020. See: https://spectrejournal.com/covid-capitalism/
} 
other alternative but to try to figure a new future that, as Roque Benavides unknowingly acknowledges in its small utopian slips, seeks to "generate well-being for the population", although what the businessman cannot accept is that this system cannot go much further, as even Vergara, who normally defends the benefits that neoliberalism brought to the country, recognizes. This desire for welfare, perhaps the only thing that liberals and socialists really share, has become impossible today without a substantial transformation of the country. Of course, the reality of mass proletarianization now in the making will be denied by the defenders of the system, and against this, it is crucial to take the ideological struggle more seriously. But today we can no longer aspire only to criticize the world, to reveal the reverse side of the dominant discourses and to remain in the comfortable position of those who are against what exists. The current task is to be able to imagine a new and better future, and to build a popular process to reach it. (July 2020)

Publisher's note Springer Nature remains neutral with regard to jurisdictional claims in published maps and institutional affiliations. 